\title{
Question webs-based learning: Science process skills and scientific questioning skills of students on harmonic motion topic
}

\author{
Ammalia Nurjannah ${ }^{a}$, Abdul Gani $^{b}{ }^{*}$, Evendi Evendi ${ }^{c}$, Muhammad Syukri $^{d}$, Elisa Elisa ${ }^{e}$ \\ Universitas Syiah Kuala. Jalan Teuku Nyak Arief No.441, Kota Banda Aceh 23111, Aceh, Indonesia \\ a ammalia.nurjannah@gmail.comb abdulgani051266@gmail.com, c evendi@unsyiah.ac.id, \\ dm.syukri@unsyiah.ac.id, e kaslielisa@unsyiah.ac.id \\ * Corresponding Author.
}

Received: 4 March 2020; Revised: 27 March 2020; Accepted: 31 March 2020

\begin{abstract}
The success of students in dealing with the globalization era of scientific literacy needs to be supported by practising skills, one of the skills that must be mastered by students in the science process skills and scientific questioning skills. This study aims to determine the implementation of the question webs based learning model of learning to improve science process skills and scientific questioning skills in grade $X$ students at SMAN 1 Darul Imarah using a quasi-experimental method with nonequivalent control group design. The samples were taken by purposive sampling technique which was then divided into experimental and control groups. The data were collected from pretest and posttest scores which were then tested based on $\mathrm{N}$-gain values. The results showed that the score of science process skills and scientific questioning skills of experimental class students obtained higher mean scores than control class mean scores. Statistically, it can be seen that testing the results of tests using the t-test 4.507 for science process skills and 29.79 for scientific questioning skills with a significant difference. The conclusion of this study shows that the question web-based learning model improve science process skills and scientific questioning skills compared to conventional models.
\end{abstract}

Keywords: question webs based learning; science process skills; scientific questioning skills

How to Cite: Nurjannah, A., Gani, A., Evendi, E., Syukri, M., \& Elisa, E. (2020). Question websbased learning: Science process skills and scientific questioning skills of students on harmonic motion topic. Momentum: Physics Education Journal, 4(1), 38-48. https://doi.org/10.21067/mpej.v4i1.4402

\section{Introduction}

Physics is one of the Natural Sciences branches that intends to develop student's skill and ability on a certain concept, principle in addition to conceptual understanding. It also allows students to be able to conduct an observation based on a scientific experiment. A learning activity that is based on the experimental procedures aims at preparing students to deal with current globalization changing in the context of education (Nasir et al., 2019). Students are expected to be able to develop their abilities and skills through experimental activities (Yumusak, 2016). It is in line with the purpose of Physics lesson, within an aspect of scientific literacy, that students are demanded to be able to improve their abilities through observation and experimental activities (Kızılaslan, 2019).

During Physics lesson activities, students must be able to develop and improve the ability of science process skills and scientific questioning skills. In recent times, Physics lesson is one of the lessons within the discipline of science that takes a role as a primary lesson in the context of education which demands teacher to train science process skills among students (Muhlisin et al., 2019). Science process skills enable the integration of student's initial ability through questioning with the acquired process skills (Ping et al., 2019). Science process skills are also important for developing 
basic thinking skills (Tilakaratne \& Ekanayake, 2017). Furthermore, students are also demanded to be able to develop their scientific questioning skills; a questioning skill that is able to be answered through experimental activities and factual reasoning. Therefore, science process skills strongly depend on the student's scientific questioning (Evendi, Susantini, Wasis, et al., 2018). Science process skills combined with scientific questioning skills in the learning process along with a concrete example allow students to be able to understand complex and abstract concepts (Af'idayani et al., 2018).

However, thus far, the learning process did not maximally train student's science process skills and scientific questioning skills. It is further supported by the results of observation conducted on SMAN 1 Darul Imarah. Based on the observation, it obtained a report that the average score of final semester examination was categorized as low skills domain, only $40 \%$ from the minimum standard of mastery (75). Recently, physics lesson remains focused on the teacher (teacher-centred learning) through conventional topic delivery; teacher explains the lesson in front of the classroom and students pay attention to the explanation and note what the teacher said. Unfortunately, this conventional learning does not enable the teacher to give a problem related to the real-life context. Consequently, students are difficult to understand and master the physics topic they learnt.

During the process of learning activities, students were only given two chances for asking questions. Furthermore, the questions proposed by the students were not a scientific question. Therefore, the conventional learning process did not provide students with a chance to develop science process skills and did not offer them direct experience in learning. Hence, this condition influenced students' learning outcomes. It was further proven by the Physics score of national examination (UN) obtained by students from the three last years: 41.92, 43.21, and 41.50 (Puspendik, 2019). Based on this condition, it is important to seek a possible solution. Based on the score of UN obtained by students during 2018/2019 academic year, the average score of mechanics topic (one of the topics was simple harmonic motion) was 26.67. The average score obtained was lower than the overall score of UN which was around 41.50 (Puspendik, 2019). According to the interview with physics teacher in the observed school, it was obtained that the average score of daily tests was 47.8 . It further confirmed that the mastery standard obtained according to the minimum mastery standard was $48 \%$ and is classified as low. The low results of learning outcomes were due to student's difficulty in understanding the abstract concept within physics lesson.

A physic lesson in school, particularly in high school, still employ conventional learning approach that focuses on achieving the score as learning outcomes instead of a comprehensive understanding of the topics. Besides, numerous teachers in the school are unable to utilize current technology to be integrated into the learning process. Thus, the learning process is less interactive and communicative in transferring knowledge to students and consequently, students have less ability in terms of questioning ability or even they are discouraged to ask for a question. Hutahaean et al. (2017) also reports that when physics lesson still uses conventional learning strategy, it only focuses on how the students memorize the formulas physics theory and how they accomplish the assignments from the teacher. Students tend to be difficult to understand the concepts of physics which most of them are abstract. Therefore, it completely ignores cognitive learning outcomes and ability acquired by students (Pratiwi et al., 2019).

The possible alternative that can be taken to resolve the current issues and to develop science process skills and scientific questioning skills of students is by applying an innovative learning strategy which consists of approaches, methods, and models that can improve students' ability. According to Nasir et al. (2019), to improve competency and balance between attitude, abilities, and knowledge, it requires a learning plan that does not only facilitate students to improve the understanding of lesson topic but also accommodates students' ability in learning. To improve science process skills and scientific questioning skills among students, teachers are able to encourage the active involvement of students and provide them with direct experience. Teachers are able to implement a certain method, model, and approach that focuses on students or commonly known as a student-centered learning strategy (Duda et al., 2019). One of the possible innovative learning models to improve science process skills and scientific questioning skills in the classroom is by 
implementing question webs-based learning (QWBL). This learning model was applied by Evendi et al. (2018). According to the results obtained, the model is effective to improve science process skills and scientific questioning skills of students in the classroom.

QWBL learning model consists of five phases as follows: (1) problem identification and purpose elaboration; (2) information delivery and arranging question webs; (3) conducting a discussion on the scientific question; (4) performing an appreciation and reflection; and (5) conducting an evaluation (Evendi, Susantini, Wasis, et al., 2018). Each phase done within QWBL is supported by the recent theoretical and empirical foundation. In addition, the model enables students to directly involved during the learning process and thus it creates a constructive learning process which does not rely on memorizing-encouraging students to think and express their ideas. The QWBL learning model is also appropriate to be applied to the Simple Harmonic Motion topic. During the lesson of Simple Harmonic Motion, students are invited to observe, formulate a hypothesis, conduct an experiment, and draw a conclusion. In addition, the students are invited to arrange scientific questions which are proven by having an experiment and observation to improve their ability and active involvement through a discussion to solve the problem related to Physics concept. Therefore, the implementation of QWBL in the learning process allows students to acquire direct experience which improves their understanding of concepts, principles, and facts as well as improving science process skills and scientific questioning skills.

Based on the explanation above, this research intended to identify and observe the implementation of QWBL learning model to improve senior high school student's science process skills and scientific questioning skills on Simple Harmonic Motion topic. In addition, this learning model allows students to acquire a comprehensive understanding of the relationship between Physics concept and the real-life phenomena.

\section{Method}

This research employed a quasi-experimental procedure with non-equivalent control group design approach. The design of this research is presented in Table 1.

Table 1. Research Design

\begin{tabular}{cccc}
\hline & Nonequivalent Control Group Design & & \\
\hline $\mathrm{O}_{1}$ & $\mathrm{X}_{1}$ & $\mathrm{O}_{2}$ & $\mathrm{O}_{2}$ \\
\hline
\end{tabular}

Remarks:

$\mathrm{O}_{1}$ : Control and Experimental Classes Pre-test

$\mathrm{O}_{2}$ : Control and Experimental Classes Post-test

$\mathrm{X}_{1}$ : Experimental Classes Treatment

$\mathrm{X}_{2}$ : Control Classes Treatment

This research took two classes: an experimental class which taught by having QWBL learning model and control class which taught by conventional lecturing learning model. The population of this research was the entire tenth graders of SMAN 1 Darul Imarah which consisted of four classes with the total students of 140 . To determine the sample of the research, it employed purposive sampling technique which was according to the homogenous score of final exam from the entire population and it took into account the consideration of Physics teachers in the school. According to the consideration, this research took two classes as the research subject; the experimental class consisting of 31 students and the control classes consisting of 30 students.

This research used the science process skills test consisting of 20 items (10 items of multiple choice and 10 items of the essay) and scientific questioning skills test consisting of 10 items as the research instrument. The test instruments were based on the indicator of science process skill according to (Nur, 2011) and the indicator of scientific questioning skills according to Evendi, Susantini, and Wasis (2018). The instruments have been valid and reliable with Cronbach's alpha test of 0.86 for science process skills instrument and 0.9 for scientific questioning skills. The tests were given to the students of both experimental and control classes twice. The first test was given before 
the learning took place-students were given a pre-test. The second test was given after the learning took place-students were given a post-test. This research was conducted on three sessions of the meeting. Each session was conducted 135 minutes. The data obtained regarding the difference of test score between experimental and control classes were observed based on $\mathrm{N}$-gain and hypothesis testing with t-test. Before administering t-test, the data were assessed whether the data were normally distributed or not. It employed a normality testing through Kolmogorov-Smirnov and homogeneity testing through Lavene test. The entire tests performed in this research were done by using statistical software called statistical package for the social sciences (SPSS) for windows version 20.

\section{Results and Discussion}

According to the normality testing, the significance values of both pre-test and post-test of science process skill were higher than alpha $=0.05$. This number further indicated that the data were normally distributed (pre-test $=0.693$ and 0.272 for experimental and control classes; post-test $=0.123$ and 0.200 for experimental and control classes). The significance values of the pre-test and post-test of scientific questioning skills were higher than alpha-0.05. This further indicated that the data were normally distributed (pre-test $=0.245$ and 0.129 for experimental and control classes; post-test $=0.447$ and 0.230 for experimental and control classes). The results of the homogeneity test from Lavene test confirmed that the data of pre-test and post-test of science process skills were homogeneous with the significance values of 0.546 (pre-test) and 0.817 (post-test). Then, the results of the homogeneity test from Lavene test confirmed that the data of pre-test and post-test of science process skills were homogeneous with the significance values of 0.198 (pre-test) and 0.758 (posttest). Based on the results obtained, it was further concluded that the data regarding science process skills and scientific questioning skills were normally distributed and homogenous.

\section{The Description of Science Process Skills Improvement}

The Analysis of Science Process Skills Results

Science Process Skills in this research were measured based on the indicator suggested by Nur (2011), i.e: formulating a problem, formulating a hypothesis, identifying a variable, defining a variable, conducting an experiment, collecting data, and drawing a conclusion. The measurement of students' science process skills was performed twice; by administering pre-test and post-test to both classes. The analysis of science process skills briefly presented in the Table 2.

Table 2. The Analysis of Science Process Skills Improvement

\begin{tabular}{lcccc}
\hline \multirow{2}{*}{ Class } & \multicolumn{2}{c}{ The average score of science process skills (\%) } & \multirow{2}{*}{ N-gain } & Category \\
\cline { 2 - 4 } & Pretest & Posttest & 0,52 & Moderate \\
\hline Control & 6,16 & 13,56 & 0,73 & High \\
Experimental & 6,29 & 16,32 & 0 \\
\hline
\end{tabular}

According to Table 2, the average score of the science process skills of students increased. This further confirms that the science process skills in both classes increased. However, based on the findings, the experimental class acquired higher science process skills improvement than the control classes. Therefore, the QWBL learning model is better to be applied during the learning process than the conventional lecturing learning model.

Statistical Testing on The Improvement of Science Process Skills

The difference in students' science process skills between experimental and control classes could be identified by using $\mathrm{t}$-test. The results of $\mathrm{t}$-test on the improvement of science process skills are presented in the Table 3.

Table 3 indicates that the score obtained from two tests performed in both classes was sig. $>0.05$. This further indicates that both data were normally distributed and homogenous. Then, the hypothesis testing obtained was $t_{\text {count }}>t_{\text {table. }}$. It further confirms that between the experimental class 
and control class there was a significant difference. The significant difference obtained was the improvement of science process skills acquired by the students on the experimental classes who were taught by the QWBL learning model. The results were higher than the control class who were taught by conventional lecturing model. A research conducted by Rismawati et al. (2017) has reported that the average score of science process skills obtained by students in the control class is lower than the experimental class. It was due to the learning model implemented by the teacher during the learning process which did not focus on the development of science process skills of students, for example, a conventional lecturing model. Furthermore, it is supported by the research of Silaban and Simajuntak (2017), that the score of science process skills improved after the teacher implemented experimental-based learning model which allows students improve the acquired abilities and obtains direct experience. Then, Sari et al. (2018) also obtained an identical result: the students' science process skills of the experimental class was higher than the control class since the students were demanded to learn actively. The students were able to acquire a better conceptual understanding from direct experience through experimental-based learning. Furthermore, it is supported by the research results of Duda et al. (2019) that the science process skills are able to be taught by using experimental-based learning method that facilitates and accommodated a collaboration among students. Based on the explanation above, it further signifies that QWBL learning model is one of the alternative strategies which within its learning process demands students to perform an experiment and answer a scientific question.

Table 3. The Hypothesis Testing Results on The Improvement of Science Process Skills

\begin{tabular}{|c|c|c|c|c|c|c|}
\hline \multirow{2}{*}{ Class } & \multirow{2}{*}{$\begin{array}{c}\text { Science Process Skills } \\
\text { Score }\end{array}$} & \multirow{2}{*}{ Normality* } & \multirow{2}{*}{ Homogeneity** } & \multicolumn{2}{|c|}{ T-test*** } & \multirow{2}{*}{ Conclusion } \\
\hline & & & & $t_{\text {count }}$ & ttable & \\
\hline Control & 13,56 & 0,272 & 0,271 & 4,50 & 1,69 & Significant \\
\hline Experimental & 16,32 & 0,693 & & & & Difference \\
\hline
\end{tabular}

Remarks:

*): Normality Test, Lcount $<$ Ltable (data was normal)

$* *$ ): Homogeneity Test, Lcount $<$ Ltable (data was homogenous)

${ }^{* * *}$ ): $t$-test, $\mathrm{t}_{\text {count }}>\mathrm{t}_{\text {table }}$ (significant difference)

The QWBL model accommodates the improvement of students' science process skills that is established according to the concepts and questions which are arranged and learnt (Evendi, Susantini, Wasis, et al., 2018). Every single phase of the QWBL model allows students to actively and logically think. The third phase, conducting a discussion on scientific questions, demands students to find proof from each scientific question through experiment. This is in line with the curriculum of Science and Technology that emphasizes science process skill as the important element within Science Education since it involves logical thinking abilities such as variable identification, formulating a hypothesis, defining element operationally, conducting an experiment, generating graph and data interpretation (Karsli \& Ayas, 2014). Furthermore, the research results obtained by (Yumusak, 2016) reported that the learning model which involves an experimental procedure and offers an opportunity to students to formulate the problems is able to improve science process skills of students. Moreover, the research conducted by Hodosyová et al. (2015) revealed that the students are demanded to acquire science process skills, thus it requires collaboration among Science teachers in school. It is in line with the research results reported by Tilakaratne and Ekanayake (2017) which revealed that science process skills of students could be improved when the teachers train the abilities independently by applying learning model which employed science process skills approach.

In addition, Science education these days has been oriented to develop students' critical thinking than only memorizing the science facts, one of them is process skill. Therefore, it could be concluded that Science lesson should emphasize its assessment and evaluation on science process skills aspect (Hussin, 2018). A practicum should be regularly conducted within Science lesson since it allows students to develop their science process skills (Ningrum et al., 2019). It is further supported by the research of Salamah and Mursal (2017) which reveal that the learning model which applies experimental procedures could improve students' process skill. According to the research results and 
supported by the previous studies, thus, the implementation of QWBL model within learning process could improve students' science process skills since it demands students to think and be proficient in determining scientific question through the experimental procedure in each phase.

The Description of Scientific Questioning Skills Improvement

\section{The Analysis of Scientific Questioning Skills Results}

Within this research, two aspects of scientific questioning skills were measured; questions based on quantity and quality. To measure the quality of scientific questioning skills, the students were given a pre-test and posttest. The results of pretest and posttest are presented in the Table 4.

Table 4. The Analysis Test of Scientific Questioning Skills Results

\begin{tabular}{|c|c|c|c|c|c|c|}
\hline \multirow[b]{2}{*}{ Class } & \multirow[b]{2}{*}{$\begin{array}{c}\text { Tes } \\
\text { Results }\end{array}$} & \multicolumn{5}{|c|}{ Quality of Students' Answers } \\
\hline & & $\begin{array}{c}\text { Highly } \\
\text { Scientific }\end{array}$ & Scientific & $\begin{array}{c}\text { Moderately } \\
\text { Scientific }\end{array}$ & $\begin{array}{c}\text { Less } \\
\text { Scientific }\end{array}$ & $\begin{array}{c}\text { Not } \\
\text { Scientific }\end{array}$ \\
\hline \multirow[t]{2}{*}{ Control } & Pretest & - & 4 & 20 & 4 & 2 \\
\hline & Posttest & 1 & 9 & 20 & - & - \\
\hline \multirow[t]{2}{*}{ Experimental } & Pretest & - & 5 & 21 & 3 & 2 \\
\hline & Posttest & 25 & 6 & - & - & - \\
\hline
\end{tabular}

Table 4 presents the implementation results of the QWBL model on physics lesson. According to Table 4, there is a significant improvement in the quality of scientific questioning in both classes. However, the improvement of the experimental class is higher than the control class. These findings further confirm that the QWBL model is better to provide an opportunity for students in improving scientific questioning skills than the conventional lecturing method. The results of scientific questioning skills were measured by using $\mathrm{N}$-gain and are presented in the Table 5.

Table 5. The Analysis of Scientific Questioning Skills Improvement

\begin{tabular}{|c|c|c|c|c|}
\hline \multirow{2}{*}{ Class } & \multicolumn{2}{|c|}{ The Average Score of Scientific Questioning Skills (\%) } & \multirow{2}{*}{$\mathrm{N}$-gain } & \multirow{2}{*}{ Category } \\
\hline & Pretest & Posttest & & \\
\hline Experimental & 19,06 & 35,54 & 0,78 & High \\
\hline Control & 17,23 & 22,40 & 0,24 & Low \\
\hline
\end{tabular}

According to Table 5 , there is a difference in the average score on scientific questioning skills and overall the results indicate an improvement. These findings reveal that the scientific questioning skills in both classes increased. However, the improvement of scientific questioning skills in the experimental class is higher than the control class. Furthermore, after implementing the QWBL model in the learning process, the students are more active in involving the lesson, raising questions particularly scientific questions. On the other hand, the students in the control class who were taught by conventional lecturing model had no courage to raise a question.

\section{The Hypothesis Testing on Scientific Questioning Skills}

The difference in students' scientific questioning skills between experimental and control classes could be identified by using t-test. The results of t-test on the improvement of scientific questioning skills are presented in the Table 6.

Table 6. Hypothesis Testing Results for Scientific Questioning Skills

\begin{tabular}{lcccccc}
\hline \multicolumn{1}{c}{ Class } & $\begin{array}{c}\text { Scientific Questioning } \\
\text { Skills Score }\end{array}$ & Normality* & Homogeneity** & \multicolumn{2}{c}{ T-test*** } & Conclusion \\
\cline { 5 - 6 } Control & 22.40 & 0.245 & 0.56 & 29.74 & 1.96 & Significant Difference \\
Experimental & 35.54 & 0.447 & & & & \\
\hline
\end{tabular}

\section{Remarks:}

*): Normality Test, Lcount $<$ Ltable (data was normal)

$\left.{ }^{* *}\right)$ : Homogeneity Test, $\mathrm{L}_{\text {count }}<\mathrm{L}_{\text {table }}$ (data was homogenous)

$* * *)$ : $t$-test, $\mathrm{t}_{\text {count }}>\mathrm{t}_{\text {table }}$ (significant difference) 
Table 6 indicates that the score obtained from two tests performed in both classes was sig. $>0.05$. This further indicates that both data were normally distributed and homogenous. Then, the hypothesis testing obtained was $t_{\text {count }}>t_{\text {table. It further confirms that between the experimental class }}$ and control class there was a significant difference. The significant difference obtained was the improvement of scientific questioning skills acquired by the students on the experimental classes who were taught by the QWBL learning model. Furthermore, the improvement in the experimental class is higher than the control class who applied conventional lecturing method. The involvement of the student in the learning process is depended on the questions raised by the teacher in the classroom. The questions raised by the teacher encourage students to develop the thinking process (Davoudi \& Sadeghi, 2015). The questions raised during the learning process will continuously develop into new questions. Through the questions, students will be able to improve their questioning skills and develop their thinking abilities to solve problems.

A question related to Physics is important within Science class and plays a role as a channel to improve student's thinking abilities (Suprapto, 2014). A graduate competence standard on the domain of abilities is also formulated by several aspects, including the aspect of questioning (Wakil Menteri Bidang Pendidikan dan Kebudayaan Republik Indonesia \& Paparan Wakil Menteri Pendidikan Pendidikan dan Kebudayaan Republik Indonesia, 2004). Therefore, the development of a learning strategy based on questioning skills must be performed to improve the abilities of students in raising a question. Davoudi and Sadeghi (2015) state that there is a correlation between how a student raises a question on the student's conceptual understanding. Hence, the teacher needs to design a learning strategy based on an experimental procedure that allows the student to raise a scientific question and assist them to improve science literacy. It is also supported by Ping et al. (2019) arguing that the learning strategy which all of students to raise questions and perform experimental procedure influences students' ability.

The Results of Quantity and Quality Analysis of Scientific Questioning Skills

Students' scientific questioning skills were also viewed based on quantity and assessed at each meeting by the observer. The results of scientific questioning skills based on quantity are stated in Table 7. The number of questions that arise from students for each meeting was different. The results obtained indicate that students are very enthusiastic to ask questions but because of insufficient time, the teacher only allowed asking just a few students while other questions were discussed outside of learning. The number of questions in the quantity and quality of the experimental class and the control class also varies. The first meeting of the experimental class (RPP-1) was 13 questions consisting of six highly scientific questions (46.16\%), five scientific questions (38.46\%), and three less scientific $(23.07 \%)$ and there were no questions which were not scientific. The teacher gave students the opportunity to ask questions five times and the number of students who asked was 39 people. The number of control class questions was 14 questions consisting of three highly scientific questions (21.42\%), four scientific (28.57\%), and six less scientific $(42.85 \%)$ and one question that was not scientific.

Table 7. The Results of Quantity and Quality Analysis of Scientific Questioning Skills

\begin{tabular}{|c|c|c|c|c|c|c|c|c|}
\hline \multirow{2}{*}{ Class } & \multirow{2}{*}{$\begin{array}{c}\text { Learning } \\
\text { Processs }\end{array}$} & \multirow{2}{*}{ KBG } & \multicolumn{2}{|c|}{ Quantity } & \multicolumn{4}{|c|}{ Quality } \\
\hline & & & JSTT & JSBT & Highly Scientific & Scientific & Less Scientific & Not Scientific \\
\hline \multirow[t]{3}{*}{ Control } & RPP-1 & 5 & 34 & 14 & 3 & 4 & 6 & 1 \\
\hline & RPP-2 & 5 & 36 & 13 & 4 & 2 & 6 & 1 \\
\hline & RPP-3 & 5 & 33 & 13 & 2 & 4 & 6 & 2 \\
\hline \multirow[t]{3}{*}{ Experimental } & RPP-1 & 5 & 39 & 13 & 6 & 5 & 3 & - \\
\hline & RPP-2 & 5 & 43 & 15 & 8 & 4 & 2 & - \\
\hline & RPP-3 & 5 & 47 & 16 & 9 & 5 & 3 & - \\
\hline
\end{tabular}

Remarks:

KBG= The Opportunity Given by Teachers

JSTT $=$ Total Number of Students Raising Their Hands

JSBT $=$ Total Number of Students Raising The Questions 
The teacher gave students the opportunity to ask questions five times and the number of students who asked was 34 students. The control class students asked 13 questions consisting of four highly scientific questions (30.76\%), two scientific questions (15.38\%), and six less scientific questions $(42.85 \%)$ and there was one very unscientific question. Furthermore, the teacher gave the opportunity for all students to ask questions, as many as 36 students raised their hand.

The number of questions raised at the second and third meetings has increased. The second meeting (RPP-2) was 15 questions consisting of eight highly scientific questions (53.33\%), four scientific questions $(26.66 \%)$ and two less scientific questions $(13.33 \%)$ and there were no unscientific questions. The last meeting was the third (RPP-3) as many as 16 questions consisting of nine highly scientific questions $(56.25 \%)$, five scientific questions $(31.25 \%)$ and one less scientific $(6.25 \%)$ and there were also no questions that were not scientific. The control class learning obtained the results of 13 questions consisting of two very scientific questions (15.38\%), four scientific questions $(30.76 \%)$, and six less scientific questions $(42.85 \%)$ and two questions were very unscientific. The teacher gave students the opportunity to ask questions five times and the number of students who asked questions was 33 . The scientific questioning skills possessed by students in the experimental class increased in each meeting and were more active in asking questions. A similar study has also been conducted by Evendi, Susantini, Wasis, et al. (2018), that students will continue to ask if they are trained and taught by the QWBL model. The third and fourth phases in the QWBL model require students to think in searching for answers to scientific questions because each indicator in a scientific question contains facts or evidence that allows for research or experimentation and should not be based on values or opinions (Evendi, Susantini, Wasis, et al., 2018).

The improvement of science process skills and scientific questioning skills are also supported by learning outcomes that have improved after applying the QWBL model. According to Evendi, Susantini, Wasis, et al. (2018) the QWBL model is also designed to see the extent to which students succeed in learning in addition to improving science process skills and also scientific questioning skills, not all questions have the same value. The cognitive level of a question is determined by its type and from the answers needed (Chin \& Osborne, 2008). For students asking their questions is the first step to find a new concept or theory for which they are still doubtful. (Chin, 2007), also states that there is a relationship between questions and learning outcomes with their conceptual understanding. Learner questions can help to monitor their questions, explore, scaffold ideas, direct thoughts in a particular direction, and advance their understanding of scientific concepts and phenomena. For teachers, these questions can be used as indicators of learning problems, and provide diagnostic information about what is needed by students (Kruea-In et al., 2015).

The improvement of student learning outcomes in the experimental class was also caused by the existence of an opportunity for students to develop the skills and knowledge they acquired. Students can understand the concepts of Physics specifically about Simple Harmonic Motion. After applying the model, students arere able to explain and understand and can analyze both the factors or characteristics of Simple Harmonic Motion. Students are also able to determine the various equations that exist in the material such as Hooke's law, period and frequency. Furthermore, it is also influenced by the proper use of student's worksheet, which guides students in the implementation of teaching and learning processes by the steps of the learning model used (Irmi et al., 2019). The results of the study (Nasir et al., 2019) also said that students are active and skilled in the classroom and could activate knowledge by asking questions and conducting experiments.

The use of the QWBL learning model has a significant effect on science process skills, scientific questioning skills and learning outcomes, compared to the conventional learning model. This is also supported by positive responses given by students, therefore this study answer the research hypothesis that the implementation of the QWBL model improves science process skills and scientific questioning skills. Thus, it is clear that in managing good learning, it is not only teachers who try but students have a very important role. Hence, the teacher and students have an interrelated relationship with one another so that the methods, approaches and learning models applied by the teacher can run well. 
The results of this study indicate that there is a relationship between students' questions and conceptual understanding and skills since every question written requires students to know the concepts being studied and proven based on experiments so as to increase the students' skills. It can also be known based on the learning outcomes obtained after applying the QWBL model in the learning process, therefore teachers need to design experimental-based learning that provides opportunities for students to ask scientific questions that help them in understanding scientific literacy. Learner questions help to monitor their questions, explore and scaffold ideas, direct thought in a particular direction and advance their understanding of scientific concepts and phenomena. For teachers, these questions can be used as indicators of student learning problems and provide diagnostic information about what is needed by students. These questions can also be used for lessons that involve class discussion, argumentation, investigation, problem-based learning, and project work.

\section{Conclusion}

Based on the research conducted, it can be concluded that the application of the QWBL model improves science process skills and scientific questioning skills of students. This paper suggests that the teacher can apply the QWBL learning model by the subject matter taught because the model can also be used for all subjects, not only Physics.

\section{References}

Af'idayani, N., Setiadi, I., \& Fahmi, F. (2018). The effect of inquiry model on science process skills and learning outcomes. European Journal of Education Studies, 4(12). https://doi.org/10.5281/ zenodo.1344846

Chin, C. (2007). Teacher questioning in science classrooms: Approaches that stimulate productive thinking. Journal of Research in Science Teaching, 44(6), 815-843. https://doi.org/10.1002/ tea.20171

Chin, C., \& Osborne, J. (2008). Students' questions: a potential resource for teaching and learning science. Studies in Science Education, 44(1), 1-39. https://doi.org/10.1080/ 03057260701828101

Davoudi, M., \& Sadeghi, N. A. (2015). A systematic review of research on questioning as a high-level cognitive strategy. English Language Teaching, 8(10), 76-90. https://doi.org/10.5539/ elt.v8n10p76

Duda, H. J., Susilo, H., \& Newcombe, P. (2019). Enhancing different ethnicity science process skills: Problem-based learning through practicum and authentic assessment. International Journal of Instruction, 12(1), 1207-1222. https://doi.org/10.29333/iji.2019.12177a

Evendi, E., Susantini, E., \& Wasis, W. (2018). Keterlaksanaan model pembelajaran berbasis jejaring pertanyaan dan kendala yang dihadapi guru dalam pembelajaran fisika. Seminar Nasional Pendidikan.

Evendi, Susantini, E., Wasis, \& Prahani, B. K. (2018). Improving students' scientific asking skills through the implementation of question webs based learning model. Journal of Physics: Conference Series, 1108, 012037. https://doi.org/10.1088/1742-6596/1108/1/012037

Hodosyová, M., Útla, J., MonikaVanyová, Vnuková, P., \& Lapitková, V. (2015). The development of science process skills in physics education. Procedia - Social and Behavioral Sciences, 186, 982989. https://doi.org/10.1016/j.sbspro.2015.04.184

Hussin, A. A. (2018). Education 4.0 made simple: Ideas for teaching. International Journal of Education and Literacy Studies, 6(3), 92. https://doi.org/10.7575/aiac.ijels.v.6n.3p.92

Hutahaean, R., Harahap, M. B., \& Derlina, D. (2017). The effect of scientific inquiry learning model using macromedia flash on student's concept understanding and science process skills in senior high school. IOSR Journal of Research \& Method in Education (IOSRJRME), 7(04), 29-37. 
Irmi, I., Hasan, M., \& Gani, A. (2019). Penerapan model inkuiri terbimbing berbantuan quick response code untuk meningkatkan ketrampilan proses sains dan hasil belajar siswa pada materi hidrolisis garam. JIPI (Jurnal IPA \& Pembelajaran IPA), 3(2), 75-87. https://doi.org/10.24815/ jipi.v3i2.14728

Karsli, F., \& Ayas, A. (2014). Developing a laboratory activity by using $5 E$ learning model on student learning of factors affecting the reaction rate and improving scientific process skills. Procedia Social and Behavioral Sciences, 143, 663-668. https://doi.org/10.1016/j.sbspro.2014.07.460

Kızılaslan, A. (2019). The development of science process skills in visually impaired students: analysis of the activities. International Journal of Evaluation and Research in Education (IJERE), 8(1), 90. https://doi.org/10.11591/ijere.v8i1.17427

Kruea-In, C., Kruea-In, N., \& Fakcharoenphol, W. (2015). A study of Thai in-service and pre-service science teachers' understanding of science process skills. Procedia - Social and Behavioral Sciences, 197, 993-997. https://doi.org/10.1016/j.sbspro.2015.07.291

Muhlisin, M., Rosiana, I., Rahayuningsih, Y., \& Suharyana, Y. (2019). The efforts to improve environmental behavior and critical thinking of students through guided inquiry-based learning on environmental education-based science. Jurnal Penelitian Dan Pembelajaran IPA, 5(2), 202. https://doi.org/10.30870/jppi.v5i2.4861

Nasir, M., Fakhrunnisa, R., \& Nastiti, L. R. (2019). The implementation of project-based learning and guided inquiry to improve science process skills and student cognitive learning outcomes. International Journal of Environmental and Science Education, 14(5), 229-238. https://doi.org/http://www.ijese.net/makale/2118.html

Ningrum, M. S., Lengkana, D., \& Yolida, B. (2019). Analisis keterlaksanaan praktikum biologi sekolah menengah atas swasta se-Kotamadya Bandar Lampung. Jurnal Bioterdidik: Wahana Ekspresi IImiah, 7(2), 56-65. http://jurnal.fkip.unila.ac.id/index.php/JBT/article/view/17262

Nur, M. (2011). Modul keterampilan-keterampilan proses sains. Pusat Sains dan Matematika Sekolah Universitas Negeri Surabaya.

Ping, I. L. L., Halim, L., \& Osman, K. (2019). The effects of explicit scientific argumentation instruction through practical work on science process skills. Jurnal Penelitian Dan Pembelajaran IPA, 5(2), 112. https://doi.org/10.30870/jppi.v5i2.5931

Pratiwi, H. Y., Hudha, M. N., Asri, M., \& Ahmad, N. J. (2019). The impact of guided inquiry model integrated with peer instruction towards science process skill and physics learning achievement. Momentum: Physics Education Journal, 3(2), 78-85. https://doi.org/10.21067/ mpej.v3i2.2768

Puspendik. (2019). Laporan hasil ujian nasional SMA/MAN tahun pelajaran 2018/2019.

Rismawati, R., Sinon, I. L. S., Yusuf, I., \& Widyaningsih, S. W. (2017). Penerapan model pembelajaran inkuiri terbimbing (guided inquiry) terhadap keterampilan proses sains peserta didik di SMK Negeri 02 Manokwari. Lectura: Jurnal Pendidikan, 8(1). https://doi.org/10.31849/ lectura.v8i1.267

Salamah, U., \& Mursal, M. (2017). Meningkatkan keterampilan proses sains peserta didik menggunakan metode eksperimen berbasis inkuiri pada materi kalor. Jurnal Pendidikan Sains Indonesia (Indonesian Journal of Science Education), 5(1), 59-65. http://www.jurnal.unsyiah. ac.id/JPSI/article/view/8408

Sari, P. M., Sudargo, F., \& Priyandoko, D. (2018). The effect of the practical-based learning model toward science process skills and concept comprehension of regulation system. JPI (Jurnal Pendidikan Indonesia), 6(2), 191-197. https://doi.org/10.23887/jpi-undiksha.v6i2.10245

Silaban, A., \& Simajuntak, M. P. (2017). Improvement of science process skill and understanding the concept of physics using inquiry learning models leading. IOSR Journal of Research \& Method in Education, 7(5), 49-52. https://doi.org/10.22611/jpf.v7i1.8644 
Momentum: Physics Education Journal, 4 (1), 2020, 48

Ammalia Nurjannah, Abdul Gani, Evendi Evendi, Muhammad Syukri, Elisa Elisa

Suprapto, N. (2014). Role of physics' questions on the improvement of thinking skills: A case of Indonesian student. International Journal of Education and Research, 2(12), 71-82.

Tilakaratne, C. T. K., \& Ekanayake, T. (2017). Achievement level of science process skills of junior secondary students: Based on a sample of grade six and seven students from Sri Lanka. International Journal of Environmental \& Science Education, 12(9), 2089-2108. http://www. ijese.net/makale/1970.html

Wakil Menteri Bidang Pendidikan dan Kebudayaan Republik Indonesia, \& Paparan Wakil Menteri Pendidikan Pendidikan dan Kebudayaan Republik Indonesia. (2004). Konsep dan implementasi Kurikulum 2013. Kementerian Pendidikan dan Kebudayaan.

Yumusak, G. K. (2016). Science process skills in science curricula applied in Turkey. Journal of Education and Practice, 7(20), 94-98. https://www.iiste.org/Journals/index.php/JEP/ article/view/31935 